\title{
The role played by granulocyte colony stimulating factor (G-CSF) on women submitted to in vitro fertilization associated with thin endometrium: systematic review
}

\author{
Mylena Naves de Castro Rocha ${ }^{1}$, Rodopiano de Souza Florêncio ${ }^{1}$, Rosane Ribeiro Figueiredo Alves ${ }^{1}$ \\ ${ }^{1}$ Humana Medicina Reprodutiva - Goiânia, GO, Brazil
}

\begin{abstract}
Objective: To provide evidence available in the literature on the role of granulocyte colony stimulating factor (G-CSF) in women submitted to in vitro fertilization, with repeated implantation failure associated with thin endometrium.

Methods: Systematic review of the use of G-CSF, as part of assisted reproduction techniques in women with repeated embryo implantation failures associated with thin endometrium. The study was carried out in the PubMed, BIREME and Elsevier databases from 2008 to 2018, in English, Spanish and Portuguese.

Results: We included all the studies, which used intrauterine G-CSF. We found an increase in endometrial thickness in eight of the 10 studies included. Of these, the implantation rate improved significantly in two studies, but the gestation rate increased in only one. We found the highest rates of implantation (32\%) and pregnancy (48\%) in a non-randomized clinical trial. On the other hand, two other studies did not demonstrate an increase in endometrial thickness and in pregnancy rates in patients with thin endometrium submitted to the assisted reproduction in frozen embryo transfer cycles.

Conclusion: Studies published so far point to a positive influence on the use of G-CSF in relation to the improvement in endometrial receptivity and pregnancy rates. Therefore, there is a need for further studies to determine whether to use it, as well as the period, route of administration, dosage and duration of treatment.
\end{abstract}

Keywords: granulocyte colony-stimulating factor, in vitro fertilization, endometrium

\section{INTRODUCTION}

Despite advances in assisted reproduction, the rates of a well-succeeded embryo implantation are still low. Embryo quality and endometrial receptivity, apart from a suitable embryo transfer technique, may influence the success of such implantation (Zenclussen \& Hämmerling, 2015; Kushnir et al., 2017). However, the morphological quality of an embryo is not a guarantee of a well-succeeded implantation. Therefore, the exclusion of an embryo with a better chance of implantation may occur, just because it was not considered the one with the best morphological aspect at the moment of evaluation (Donadio et al., 2012).

Conversely, it is believed that the adequate endometrial thickness could make the endometrial cells change into decidual easier, as well as the invasion of blastocysts and a timely placenta growth (Zenclussen \& Hämmerling, 2015). However, there is no agreement in the literature regarding endometrial thickness to characterize a receptive endometrium. A thin endometrium is seen more often in women aged over 40 , probably due to vascularity decrease. A $2.4 \%$ to $5 \%$ prevalence of thin endometrium has been reported in women under 40 years of age, and $25 \%$ in women over 40 in natural cycles (Sher et al., 1991; Kasius et al., 2014).

There are studies which indicate a thickness threshold below 7mm (Mahajan \& Sharma, 2016; Cavalcante et al., 2015), yet others report $6 \mathrm{~mm}$ (Shapiro et al., 1993; Kunicki et al., 2014) or $8 \mathrm{~mm}$ (Gingold et al., 2015). On the other hand, a study reports clinical pregnancy with $4 \mathrm{~mm}$ of endometrial thickness (Check et al., 2016), which brings about the possibility that the endometrial receptivity may not necessarily be related to the endometrial thickness. In spite of not having a consensus, endometrial thickness has been used to predict the likelihood of pregnancy in assisted reproduction cycles.

Today, there are pieces of evidence that the embryonic implantation process turned easier by immune cells, growth factors, cytosines, and hormonal changes (Kunicki et al., 2014; Davari-Tanha et al., 2016; Eftekhar et al., 2016a). G-CSF is a hemanopoietic cytosine produced in the reproductive system, at the maternofetal interface, during embryo implanting, which stimulates granulocyte proliferation and differentiation. It has been suggested that this cytosine could, therefore, play a role both on the decidua and the placental function (Salmassi et al., 2004; Li et al., 2014; Cavalcante et al., 2015). G-CSF for clinical use is mainly indicated to reduce neutropenia duration and fevered neutropenia incidence in patients with non-myelogenic neoplasia, undergoing cytotoxic chemotherapy. Besides this, it is also indicated to reduce neutropenia duration and after-effects in patients submitted to myeloablative therapy followed by bone marrow transplant (Wurfel, 2015). Synthetic G-CSF differs from its natural counterpart for presenting an additional $\mathrm{N}$-methionine terminal residue and for the lack of O-Glycogenesis. In Brazil this drug is traded under the name Filgastrim (Granulokine; Roche), presented in pre-bottled syringes holding $0.5 \mathrm{~mL}$ injectable solution, containing $300 \mu \mathrm{g}$, which comprises 30 million units.

The first evidence of improvement on in vitro fertilization embryo implanting rates and higher G-CSF concentration in follicular liquid was reported in 2005 (Salmassi et al., 2005). Since that time, some studies have evaluated G-CSF usage in a systemic form via subcutaneous injection or directly in the endometrium via intrauterine injection (Kunick et al., 2014, Li et al., 2014), in women with recurrent spontaneous abortion and repeated implantation failures. Others show pregnancy improved results (Santjohanser et al., 2013; Eftekhar et al., 2016b), even in those with thin endometrium (Gleicher et al., 2013; Lucena \& Moreno-Ortiz, 2013). Thus, the objective of this study was to systematize the literature evidence on the use of G-CSF and pregnancy rates in women submitted to assisted reproduction techniques (ART) with repeated failures associated with thin endometrium. 


\section{MATERIALS AND METHODS}

This systematic review study included papers published in English, Spanish, and Portuguese, which investigated the use of intrauterine or subcutaneous G-CSF in cases of implantation failure, associated with thin endometrium in the context of human assisted reproduction. We searched in PubMed, Bireme and Elsevier databases, using the following keywords: "granulocyte colony-stimulating factor" [MeSH Terms] AND "endometrium"[MeSH Terms] AND ("humans"[MeSH Terms] AND (English [lang] OR Portuguese[lang] OR Spanish[lang])) in a-10 year period (from January 2008 to March 2018).

Two independent authors read the titles and abstracts in order to check for duplicates and to meet the pre-established inclusion criteria. Afterwards, they read the potentially eligible papers entirely. Those papers, which despite reporting the use of G-CSF in human reproduction did not evaluate its impact on endometrial thickness and on pregnancy rates, we discarded. The data was extracted from the text, tables, and graphs in the studies included. We collected information such as study type, place and year of publication, number and age of participants, the timeframe and G-CSF administration via, endometrial thickness before and after G-CSF, and pregnancy rates.

\section{RESULTS}

We selected 161 papers: 23 from PubMed, 94 from Bireme, and 44 from Elsevier (Figure 1). Five papers were taken off for being duplicated, 78 for not addressing the G-CSF regarding repeated failures associated with thin endometrium, and 68 for addressing other indications regarding the use of G-CSF. In our study, 10 papers were included, namely, two randomized clinical trials (Eftekhar et al., 2016b; Sarvi et al., 2017), three not-randomized clinical trials (Xu et al., 2015; Tehraninejad et al., 2015; Eftekhar et al., 2014), three prospective cohort studies (Shah et al., 2014; Gleicher et al., 2011; 2013) and two cross-sectional studies (Mishra et al., 2016; Kunicki et al., 2014).

Out of these 10 studies, seven were published in the Asian continent, one in the European, and two in the American continent (Chart 1 ). These papers were published from 2011 to 2017 and included 475 participants with thin endometrium and repeated failures in the assisted reproduction techniques to whom, G-CSF was employed. The average age range of the participants included in the published studies was from 30.5 to 40.5 . All of the 10 studies included utilized G-CSF via uterine at a $300 \mathrm{mcg}$ dosage. The G-CSF application day concerning the menstrual cycle period varied among the studies (Chart 1 ).

Three out of the five clinical trials evidenced significant increases on the endometrial thickness with the use of G-CSF (Sarvi et al., 2017; Xu et al., 2015; Tehraninejad et al., 2015); three prospective cohorts (Shah et al., 2014; Gleicher et al., 2011; 2013) and two out of the cross-sectional studies (Mishra et al., 2016; Kunicki et al., 2014) included in the present review. The pregnancy rates in the studies, which showed endometrial thickness significant increase, ranged from $19.1 \%$ to $37.0 \%$ (Chart 1 ).

Three non-randomized clinical trials (Eftekhar et al., 2014; Tehraninejad et al., 2015; Xu et al., 2015) and two randomized clinical studies (Eftekhar et al., 2016b; Sarvi et al., 2017) showed implantation rate increase. Despite the small number of participants involved in the included randomized trials, the implantation rate ranged from 10 to $17 \%$ and the pregnancy was $29 \%$ after G-CSF treatment. Three out of the ten included studies did not evidence improvements in pregnancy rates (Eftekhar et al., 2014; Mishra et al., 2016; Sarvi et al., 2017). As for the other seven studies, the rates ranged from 19 to $37 \%$ (Gleicher et al., 2011; 2013; Kunicki et al., 2014; Shah et al., 2014; Tehraninejad et al., 2015; Xu et al., 2015; Eftekhar et al., 2016b). The highest clinical pregnancy rate (28.8\%) was found in the randomized clinical trial (Eftekhar et al., 2016b) and, the rate in the implantation group, treated with G-CSF, was $17 \%$; whereas in the control group, it was $5 \%(p<0.05)$.

\section{DISCUSSION}

Intrauterine G-CSF infusion in assisted reproduction cycles aims at increasing the endometrial receptivity and, thus, reshape and increase endometrium thickness. Therefore, it would help the embryo transfer and clinical pregnancy rates (Eftekhar et al., 2014; Kunicki et al., 2014; Eftekhar et al., 2016a; b). Nonetheless, literature data is not conclusive regarding what it considers as thin or unresponsive endometrium. Some studies state that pregnancy takes place when the endometrium reaches over $7 \mathrm{~mm}$ (Gleicher et al., 2013; Gingold et al., 2015), and others say that more than $9 \mathrm{~mm}$ is required (Kasius et al., 2014; Mahajan \& Sharma, 2016). Besides this, there is strong evidence that the thin endometrium is not necessarily a factor, which hinders, a well-succeeded embryo implanting. There is evidence that the thin endometrium is not necessarily a factor preventing successful embryo implantation, although it may negatively affect pregnancy after embryo transfers (Gingold et al., 2015; Mahajan \& Sharma, 2016).

The studies included in this review, demonstrated an effect considered moderate, on the unresponsive endometrium treatment, with low implantation and pregnancy rates. G-CSF use as an additive in assisted reproduction treatment, aiming at enhancing endometrial receptivity, is new. It is expected, though, that G-CSF will be an outstanding agent in assisted reproduction (Eftekhar et al., 2016a; Sarvi et al., 2017).

Randomized clinical trials are taken as standard of excellence to evaluate the efficacy of an intervention. So, the results presented by Eftekhar et al. (2016b) and Sarvi et al. (2017), concerning thin endometria and low implantation and pregnancy rates, provide resources to carry out trials with higher number of participants aiming at evaluating the G-CSF efficacy. Another important factor to be noticed is that there was no homogeneity on the treatment utilized in the evaluated trials, neither with regards to intrauterine infusion day nor number and dose applied. Therefore, there is a need for better evidence about number and dose, and on the cycle phase they should be administered. In addition to this, the timeframe between intrauterine infusion and endometrium evaluation is not well-grounded in literature. Gleicher et al. (2011), did the re-evaluation at $48 \mathrm{~h}$, time much shorter than the one reported by Kunicki et al. (2014).

One of the earlier publications regarding its use dates back to 2011 (Gleicher et al., 2011). However, over these seven years, few clinical essays were performed with few participants, which constraints the conclusion with regards to the benefit or not of its use, in assisted reproduction. Thus, despite improvements in endometrial thickness associated with increases in pregnancy rates, confirmed in eight studies in the present review (Gleicher et al., 2011; 2013; Shah et al., 2014; Kunicki et al., 2014; Tehraninejad et al., 2015; Xu et al., 2015; Mishra et al., 2016; Sarvi et al., 2017), the results are not sufficient yet to provide a robust evidence for the use of G-CSF in patients with thin endometria, as well as repeated failures both at implantation and pregnancy rates. In a cohort study, all of the treated patients improved their endometrial thickness at an average of $3.54 \mathrm{~mm}$ upon treatment and, at the moment of 


\section{Articles identified via database research:}

PUBMED: 23

BIREME: 94

ELSEVIER: 44

Filters applied:
Articles published in English,
Spanish, and Portuguese languages,
feminine sex, from January 2008 to
March 2018

'granulocyte colony-stimulating factor' [MeSH Terms] AND

"endometrium"[MeSH Terms] AND

("humans"[MeSH Terms] AND (English[lang] OR Portuguese[lang] OR Spanish[lang]))

\section{Articles excluded after title and} summary reading:

Duplicate: 5

Did not meet the threshold: 78

Number of cases: 2

Case report: 2

Other indications of G-CSF: 61 


\begin{tabular}{|c|c|c|c|c|c|c|}
\hline $\begin{array}{l}\text { First author/ } \\
\text { Year } \\
\text { Geographic } \\
\text { Region }\end{array}$ & Study Type & $\begin{array}{c}\text { Participants } \\
\text { number }\end{array}$ & Average age & $\begin{array}{l}\text { G-CSFmethod } \\
\text { of use Date }\end{array}$ & $\begin{array}{c}\text { Endometrium } \\
\text { thikness } \\
\text { after G-CSF } \\
\text { (average) }\end{array}$ & $\begin{array}{l}\text { Pregnancy } \\
\text { rates (\%) }\end{array}$ \\
\hline $\begin{array}{l}\text { Sarvi et al., } \\
2017 \text { Iran }\end{array}$ & RCT & TG: 13 CG: 15 & $\begin{array}{c}\text { TG: } 31.2 \text { CG: } \\
31.6\end{array}$ & $\begin{array}{l}\text { TG: } 300 \text { mcg } \\
\text { IU GC: Saline }\end{array}$ & TG: $5 \pm 1.4 \mathrm{~mm}$ & $\begin{array}{c}\text { CG: } 20 \text { TG: } \\
15.3^{* *}\end{array}$ \\
\hline $\begin{array}{l}\text { Eftekhar et al., } \\
\text { 2016b Iran }\end{array}$ & RCT & TG: 44 CG: 45 & $\begin{aligned} \text { TG: } & 32.5 \text { CG: } \\
& 31.7\end{aligned}$ & $300 \mathrm{mcg} I U$ & $\begin{array}{c}\text { CG: } 8.8 \text { TG: } \\
9.1 * *\end{array}$ & $\begin{aligned} & \text { TG: } 28.8 \text { CG: } \\
& 1.3^{*}\end{aligned}$ \\
\hline $\begin{array}{l}\text { Xu B et al., } \\
2015 \text { China }\end{array}$ & $\begin{array}{c}\text { Non- } \\
\text { randomized CT }\end{array}$ & TG: 41 CG: 65 & $\begin{aligned} \text { TG: } & 31.4 \mathrm{CG}: \\
& 32.0\end{aligned}$ & 300 mcg IU & $\begin{array}{l}5.7 \mathrm{~mm} \text { antes } \\
8.4 \mathrm{~mm} \text { após* }\end{array}$ & $\begin{array}{c}\text { TG: } 48 \text { CG: } \\
25^{*}\end{array}$ \\
\hline $\begin{array}{l}\text { Tehraninejad } \\
\text { et al., } 2015 \\
\text { Iran }\end{array}$ & $\begin{array}{c}\text { Non- } \\
\text { randomizedCT }\end{array}$ & 15 & 35.13 & $\begin{array}{c}300 \text { mcg IU } \\
\text { eggs collecting } \\
\text { day }\end{array}$ & $\begin{array}{l}3.6 \mathrm{~mm} \text { antes } \\
7.1 \mathrm{~mm} \text { após* }\end{array}$ & 20 \\
\hline $\begin{array}{l}\text { Eftekhar et al., } \\
2014 \text { Iran }\end{array}$ & $\begin{array}{c}\text { Non- } \\
\text { randomized CT }\end{array}$ & TG: 34 CG: 34 & $\begin{aligned} \text { TG: } & 30.8 \mathrm{CG}: \\
& 28.6\end{aligned}$ & $\begin{array}{c}300 \text { mcg IU } \\
12 \text { th to } 13 \text { th } \\
\text { day }\end{array}$ & $\begin{array}{c}5.6 \text { CG 5.8: } \\
\text { TG** }\end{array}$ & $\begin{array}{c}\mathrm{CG}: 28.6 \\
\mathrm{TG}: 30.8 * *\end{array}$ \\
\hline $\begin{array}{l}\text { Shah et al., } \\
2014 \text { India }\end{array}$ & $\begin{array}{l}\text { Prospective } \\
\text { cohort study }\end{array}$ & $\begin{array}{c}\text { EG: } 231 \text { NEG: } \\
117\end{array}$ & 33.5 & $\begin{array}{c}300 \mathrm{mcg} \text { IU } \\
10 \text { days from } \\
\text { estrogen onset }\end{array}$ & $\begin{array}{l}<8 \mathrm{~mm} \text { before } \\
10.9 \mathrm{~mm} \text { after* }\end{array}$ & 37 \\
\hline $\begin{array}{l}\text { Gleicher et al., } \\
2013 \text { USA }\end{array}$ & $\begin{array}{l}\text { Prospective } \\
\text { cohort study }\end{array}$ & 21 & 40.5 & $\begin{array}{c}300 \text { mcg IU on } \\
\text { hCG day }\end{array}$ & $\begin{array}{l}5.7 \mathrm{~mm} \text { before } \\
9.3 \mathrm{~mm} \text { after* }\end{array}$ & 19.1 \\
\hline $\begin{array}{l}\text { Gleicher et al., } \\
2011 \text { USA }\end{array}$ & $\begin{array}{l}\text { Prospective } \\
\text { cohort study }\end{array}$ & 4 & 38.3 & $\begin{array}{c}300 \mathrm{mcg} \text { IU } 48 \\
\text { h beforeET }\end{array}$ & $\begin{array}{l}4.9 \mathrm{~mm} \text { before } \\
8.7 \mathrm{~mm} \text { after* }\end{array}$ & 100 (1 ectopic) \\
\hline $\begin{array}{l}\text { Mishra et al., } \\
2016 \text { India }\end{array}$ & $\begin{array}{c}\text { Cross-sectional } \\
\text { study }\end{array}$ & 35 & 30.5 & $\begin{array}{c}300 \mathrm{mcg} \text { IU } \\
\text { on } 14 \text { th day of } \\
\text { cycle }\end{array}$ & $\begin{array}{l}5.9 \mathrm{~mm} \text { before } \\
6.6 \mathrm{~mm} \text { after* }\end{array}$ & Zero \\
\hline $\begin{array}{l}\text { Kunicki et al., } \\
2014 \text { Poland }\end{array}$ & $\begin{array}{c}\text { Cross-sectional } \\
\text { study }\end{array}$ & 37 & 34.7 & $\begin{array}{c}300 \text { mcg IU on } \\
\text { hCG day }\end{array}$ & $\begin{array}{c}6.7 \text { before } 8.4 \\
\text { after* }\end{array}$ & 19.1 \\
\hline
\end{tabular}

RCT: Randomized clinical trial. IU: intrauterine; ET: Embryo Transfer; CT: Clinical Trial;

SD: Standard Deviation; IR: implantation Rate; *: Significant; **:not significant. TG: Treated Group.

CG: Control Group, EG: Exposed Group; NEG: Non-Exposed Group.

well as for the different types of studies. There is a must for more controlled randomized studies involving a larger number of participants to make it possible to establish the correct prescription, as well as the suitable dose and the treatment timeframe.

\section{ACKNOWLEDGEMENTS}

In this study, I counted on the support and collaboration of very special people, who became even more important in my professional carrier. For them, I express my recognition; above all, for the incentive and the support to overcome great limits and difficulties, at this time of my living.

\section{CONFLICT OF INTERESTS}

There is not any conflict of interests on the proposed study we carried out here.

\section{Corresponding author:}

Mylena Naves de Castro Rocha

Humana Medicina Reprodutiva.

Goiânia, GO, Brazil.

E-mail: dramylenarocha@gmail.com

\section{REFERENCES}

Cavalcante MB, Costa Fda S, Barini R, Araujo Júnior E. Granulocyte colony-stimulating factor and reproductive medicine: A review. Iran J Reprod Med. 2015;13:195-202. PMID: 26131007
Check JH, Choe JK, Summers-Chase D. Failure to increase the thickness of thin endometria with intrauterine infusion of granulocyte colony stimulating factor (G-CSF). Clin Exp Obstet Gynecol. 2016;43:332-3. PMID: 27328485

Davari-Tanha F, Shahrokh Tehraninejad E, Ghazi M, Shahraki $Z$. The role of G-CSF in recurrent implantation failure: A randomized double blind placebo control trial. Int J Reprod Biomed (Yazd). 2016;14:737-42. DOI: 10.29252/ijrm.14.12.737

Donadio NF, Dzik A, Cavagna M, Donadio N. Fertilização In Vitro. In: Dzik A, Donadio NF, Esteves SC, Nagy ZP, eds. Atlas de Reprodução Humana. São Paulo: Segmento Farma; 2012. p. 123-9.

Eftekhar M, Sayadi M, Arabjahvani F. Transvaginal perfusion of G-CSF for infertile women with thin endometrium in frozen ET program: A non-randomized clinical trial. Iran J Reprod Med. 2014;12:661-6. DOI: 10.29252/ijrm.14.5.341

Eftekhar M, Hosseinisadat R, Baradaran R, Naghshineh E. Effect of granulocyte colony stimulating factor (G-CSF) on IVF outcomes in infertile women: An RCT. Int J Reprod Biomed (Yazd). 2016a;14:341-6. PMID: 27326420 DOI: 10.29252/ijrm.14.11.687

Eftekhar M, Miraj S, Farid Mojtahedi M, Neghab N. Efficacy of Intrauterine infusion of granulocyte colony stimulating factor on patients with history of implantation failure: A randomized control trial. Int J Reprod Biomed (Yazd). 2016b;14:687-90. PMID: 27981253 
Gingold JA, Lee JA, Rodriguez-Purata J, Whitehouse MC, Sandler B, Grunfeld L, Mukherjee T, Copperman AB. Endometrial pattern, but not endometrial thickness, affects implantation rates in euploid embryo transfers. Fertil Steril. 2015;104:620-8.e5. PMID: 26079695 DOI: 10.1016/j. fertnstert.2015.05.036

Gleicher N, Vidali A, Barad DH. Successful treatment of unresponsive thin endometrium. Fertil Steril. 2011;95:2123. e13-7. PMID: 21324451 DOI: 10.1093/humrep/des370

Gleicher N, Kim A, Michaeli T, Lee HJ, Shohat-Tal A, Lazzaroni E, Barad DH. A pilot cohort study of granulocyte colony-stimulating factor in the treatment of unresponsive thin endometrium resistant to standard therapies. Hum Reprod. 2013;28:172-7. PMID: 23081869 DOI: 10.1093/ humrep/des 370

Kasius A, Smit JG, Torrance HL, Eijkemans MJ, Mol BW, Opmeer BC, Broekmans FJ. Endometrial thickness and pregnancy rates after IVF: a systematic review and meta-analysis. Hum Reprod Update. 2014;20:530-41. PMID: 24664156 DOI: 10.1093/humupd/dmu011

Kunicki M, Łukaszuk K, Woclawek-Potocka I, Liss J, Kulwikowska $P$, Szczyptańska J. Evaluation of granulocyte colony-stimulating factor effects on treatment-resistant thin endometrium in women undergoing in vitro fertilization. Biomed Res Int. 2014;2014:913235. PMID: 24693540 DOI: $10.1155 / 2014 / 913235$

Kushnir VA, Barad DH, Albertini DF, Darmon SK, Gleicher $\mathrm{N}$. Systematic review of worldwide trends in assisted reproductive technology 2004-2013. Reprod Biol Endocrinol. 2017;15:6. PMID: 28069012 DOI: 10.1186/s12958-0160225-2

Li Y, Pan P, Chen X, Li L, Li Y, Yang D. Granulocyte colony-stimulating factor administration for infertile women with thin endometrium in frozen embryo transfer program. Reprod Sci. 2014;21:381-5. PMID: 23885097 DOI: $10.1177 / 1933719113497286$

Lucena E, Moreno-Ortiz H. Granulocyte colony-stimulating factor (G-CSF): a mediator in endometrial receptivity for a patient with polycystic ovary (PCO) undergoing in vitro maturation (IVM). BMJ Case Rep. 2013;2013. pii: bcr2012008115. PMID: 23605819 DOI: $10.1136 / \mathrm{bcr}-$ 2012-008115

Mahajan N, Sharma S. The endometrium in assisted reproductive technology: How thin is thin? J Hum Reprod Sci. 2016;9:3-8. PMID: 27110071 DOI: 10.4103/09741208.178632

Mishra VV, Choudhary S, Sharma U, Aggarwal R, Agarwal R, Gandhi K, Goraniya N. Effects of Granulocyte Colony-Stimulating Factor (GCSF) on Persistent Thin Endometrium in Frozen Embryo Transfer (FET) Cycles. J Obstet Gynaecol India. 2016;66:407-11. PMID: 27651638 DOI: $10.1007 / \mathrm{s} 13224-015-0775-9$
Salmassi A, Schmutzler AG, Huang L, Hedderich J, Jonat W, Mettler L. Detection of granulocyte colony-stimulating factor and its receptor in human follicular luteinized granulosa cells. Fertil Steril. 2004;81:786-91. PMID: 15019810 DOI: $10.1016 /$ j.fertnstert.2003.09.039

Salmassi A, Schmutzler AG, Schaefer S, Koch K, Hedderich J, Jonat W, Mettler L. Is granulocyte colony-stimulating factor level predictive for human IVF outcome? Hum Reprod. 2005;20:2434-40. PMID: 15890733 DOI: 10.1093/ humrep/dei071

Santjohanser C, Knieper C, Franz C, Hirv K, Meri O, Schleyer M, Würfel W, Toth B. Granulocyte-colony stimulating factor as treatment option in patients with recurrent miscarriage. Arch Immunol Ther Exp (Warsz). 2013;61:159-64. PMID: 23344173 DOI: 10.1007/s00005-012-0212-z

Sarvi F, Arabahmadi M, Alleyassin A, Aghahosseini M, Ghasemi M. Effect of Increased Endometrial Thickness and Implantation Rate by Granulocyte Colony-Stimulating Factor on Unresponsive Thin Endometrium in Fresh In Vitro Fertilization Cycles: A Randomized Clinical Trial. Obstet Gynecol Int. 2017;2017:3596079. PMID: 28791050 DOI: $10.1155 / 2017 / 3596079$

Shah J, Gangadharan A, Shah V. Effect of intrauterine instillation of granulocyte colony-stimulating factor on endometrial thickness and clinical pregnancy rate in women undergoing in vitro fertilization cycles: an observational cohort study. Int J Infertil Fetal Med. 2014;5:100-6. DOI: 10.5005/jp-journals-10016-1090

Shapiro H, Cowell C, Casper RF. The use of vaginal ultrasound for monitoring endometrial preparation in a donor oocyte program. Fertil Steril. 1993;59:1055-8. PMID: 8486173 DOI: $10.1016 /$ S0015-0282(16)55927-5

Sher G, Herbert C, Maassarani G, Jacobs MH. Assessment of the late proliferative phase endometrium by ultrasonography in patients undergoing in-vitro fertilization and embryo transfer (IVF/ET). Hum Reprod. 1991;6:232-7. PMID: 2056019 DOI: $10.1093 /$ oxfordjournals.humrep.a137312

Tehraninejad E, Davari Tanha F, Asadi E, Kamali K, Aziminikoo E, Rezayof E. G-CSF Intrauterine for Thin Endometrium, and Pregnancy Outcome. J Family Reprod Health. 2015;9:107-12. PMID: 26622308

Wurfel W. Treatment with granulocyte colony-stimulating factor in patients with repetitive implantation failures and/or recurrent spontaneous abortions. J Reprod Immunol. 2015;108:123-35. PMID: 25740726 DOI: 10.1016/j. jri.2015.01.010

Xu B, Zhang Q, Hao J, Xu D, Li Y. Two protocols to treat thin endometrium with granulocyte colony-stimulating factor during frozen embryo transfer cycles. Reprod Biomed Online. 2015;30:349-58. PMID: 25682303 DOI: 10.1016/j. rbmo.2014.12.006

Zenclussen AC, Hämmerling GJ. Cellular Regulation of the Uterine Microenvironment That Enables Embryo Implantation. Front Immunol. 2015;6:321. PMID: 26136750 DOI: 10.3389/fimmu. 2015.00321 